\title{
舞踊の認知構造について
}

世阿弥能芸論の舞踊意味論的分析の武み*

\author{
大 城 冝 武 (沖䋥キリスト教短期大学) \\ （昭和52年 6 月 21 日 受付）
}

\section{A Pilot Study of Zeami's Theory of Noh: Towards a Semantics of Dance}

\author{
Yoshitake Oshiro**
}

\begin{abstract}
The aim of this study is to analyze the features of the theory of Noh proposed by its founder, Zeami, from the view point of the semantics of dance. The semantics of dance which is rather a working hypothesis at present, is designed to move toward the construction of general theory of dance.

First of all, Zeami's view of the succession and development of the art of Noh is discussed. Zeami claims that the fundamental conditions for the succession and development of the Noh are to continue hard exercises, to master the techniques of performing, and to compose Noh play. Zeami sets nine stages of practice for Noh.

Secondly, The Nikyoku-Santai-ron, which is the discipline of exercises or practice of Noh, compared with Laban's theory of "Effort". It is suggested in this study that these two disciplines have some similarities.

Thirdly, by using the results in the field of semiotics and psychology, the MokuzenShingo-setsu, which is the performer's preparation for the performance of Noh, is discussed. Mead's theory of "self" is applied to the analysis of this theory. Zeami's disciplines of Gaken, Riken, and Riken-no-Ken, which are stated in the same line of the Mokuzen-Shingo-setsu, seem to be in correlation to the "I", "me", and "self" in the Mead's theory. Zeami argues the importance of the spectator or decoder in the process of performing Noh, by which his theory of Noh is charactrized.

By using the above results, the working hypothesis concerning the process of performing dance is revised and enlarged.

(Yoshitake Oshiro : A Pilot study of Zeami's Theory of Noh: Towards a Semantics of Dance. Jap. J. Phys. Educ., Vol. 23, No. 1, Jun., 1978, pp. 1 12)
\end{abstract}

* 本研究は昭和 51 年度「大谷研究梨励金」による研究報告の一部である。

** Okinawa Christian Junior College, Naha, Okinawa (1903) 


\section{はじめに}

舞踊活動は，舞踊作品を核とする，作舞者，演 舞者，そして観舞者を含む過程である。従来，舞 踊研究は，たとえば創作論，作品論，演舞論，ま たは，鑑賞論などとして個別的に遂行された傾向 が著しい。しかし，これらの個別的諸研究は，最 終的にはある種の統一原理に基ついて，総合化， 体系化される必要があると思われる。

本研究は，舞踊の一般理論を確立することをめ さしてなされている一連の舞踊基磷論研究の一部 をなすものである，われわれは，舞踊基礎論を 「舞踊意味論」仮説に求めている. そして, 本稿 の目的は，舞踊意味論的観点から，世阿弥の「能 芸論」の特質のいくつかを解明することである. この分析作業を通して，舞踊意味論仮説の有効性 を検討し，この仮説に舞踊基礎論としての補正修 正を施すことを企図している。

近年，世阿弥または能楽論に関する研究分野 は，相当の文献的な蓄積がなされている80)81).

しかし，この文献量の多さにもかかわらず，能 楽研究は，その低迷状況が指摘されている ${ }^{80)}$ 。 ま た，この分野は，「歴史が浅くてやることはいく

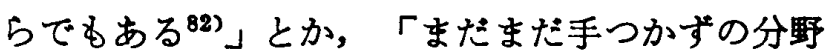
が多いのであってむしろ，前途茫洋の感さ壳あ る ${ }^{17)}$ 」評され，「新しい視野からの見直し81)」 が要請されている.このような現況にあって，舞 踊意味論は，能楽研究へのひとつの新しい視野を 提供する試みとなるであろう．ただし，舞踊意味 論は，作業仮説，ここでは試論の範囲を越えるも のではありえない。

後藤は，能の成立について次のよ5に記してい る;

能は鎌倉時代から南北朝時代にかけて，民衆 - 珷家に支持され，地方垠村の寺社で広く行な われていた猿楽・田楽が発展成長したものであ るといわれている゙。

北川は，世阿弥の父，観阿弥時代の能を以下のよ 5 に説明する;

観阿弥時代の能は正しく大衆演劇で，自作自 演，演出も自由，舞踊をとり入れようが音曲を 変更しよ5が，全く意のままであった。要は大
衆にアッピールして，芸能人として名声を博せ ばよかったのである(5).

この頃，能が創成期の熱気に溢れていたことがわ かる.また，北川は，世阿弥を「能役者であり， 能作者であり，そして一座の統率者・演出家であ ったが，今一つ能理論家として勝れた才能を持っ

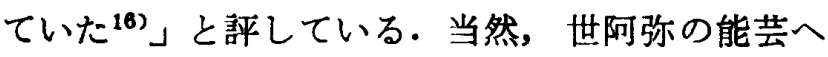
の目配りは行き届いている.すなわち，世阿弥の 能芸論は多岐にわたっている，たと点ば，皘古 論, 演技論, 演者論, 習道体系論, 芸位論, 作品 論, 作能䜽, 音曲論, 作曲論, 能芸美論, 観客 論，演出論といった具合であるしかし，世阿弥 は単なる理論家ではなかった。表章は次のように 述べている；

世阿弥の能楽論は, 彼の能役者としての活動 と一体の関係で展開している.そして理論が先 行し，それを指標として彼の演能活動が展開さ れたのではなく，作品と舞台とで実胃した能の 改革を追いかけ，経験を後に理論化する形で能 楽論が書かれているのである・世阿弥は評論家 ではなく，あくまです能役者であった 世阿弥は，理論家である以前に実践家であった。 はじめに能の経験があって, 彼の能経験は理論化 され，伝書となって結実していく，当時, 猿楽や 田楽の諸座が，「地方大衆の人気をむとめ, 寺社 - 貫族・武士の棟梁・殊に将軍の保揽をるとめ

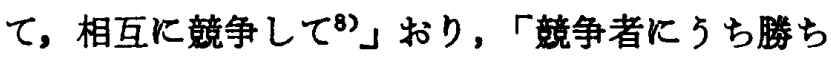
権力者の気に入る芸を見せることが，当然能役者 たちの死活問題"」」であった。したがって，一座 の，そして能芸存続のために「戦 5 世阿弥は戦術 的な極意を伝えよ5として，その能楽論を書い だ)」とされる.山崎は，「世阿弥の芸術理論は さしあたり極度に戦術的な色彩を带びさるをえな

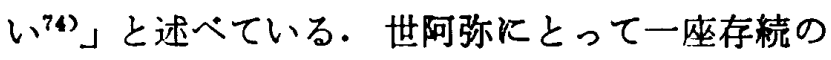
可否は重大な課題であった。一座のそして能の存 続と展開の期待のもとに能楽論畵は著わされたと いえよ5。

断るまでもなく，能は現在も行なわれている. しかし, 本稿の範囲はもっばら, 世阿弥伝書に記 されたいくつかの問題に限定され，世阿弥能芸論 と現行能との関わり等については視野の外にあ り，今後の課題としたい. 


\section{I 舞踊意味埇}

（作業仮説）

舞踊は表現的形式 expressive form の一種であ る25).あるいは現示的形式 representative form である.舞踊そして芸術一般を「記号」と規定す る観点が，舞踊意味論そして芸術記号論の立場で ある12)18359861)。本研究の拠点とする舞踊意味論の 基本仮説を作業仮説の形で以下に揭げる.

仮説 1 舞踊は記号 sign である。

仮説 2 舞踊過程は記号の使用過程である。この 記号の使用が
a 、探求的・創造的であれば創作過程
b. 理解的・表現的であれば演舞過程
c. 享受的・評価的であれば鑑筫過程 である。

仮説 3 舞踊過程は演舞者による作舞者から観舞 者への舞踊作品の伝達過程である.

仮説 4 作舞者は観舞者の作品への藷反応によっ て，その作品を修正し，より適合したも のにする.

仮説 5 演舞者は，観舞者の演舞への諸反応によ ってその演舞を修正し，より適合したも のにする。

仮説 6 舞踊認知は通常演舞を通してなされる。

仮説 7 舞踊過程は複数の伝達チャンネルを持 ว.

仮説 8 舞踊認知は作舞者, 演舞者, 観舞者の先 行経験によって規定される。

仮説 9 舞踊の認知構造は比較的安定している.

仮説10 舞踊の伝達過程のあらゆる場面でノイズ が発生する。

仮説11 ある特定の個人または集団が
a . 作舞者と演舞者
b. 作舞者と観舞者
c . 演舞者と観舞者
d. 作舞者, 演舞者, 観舞者 を兼ねることができる。

仮説12 舞踊作品は共通の認知枠組みの中に整 理・分類，関連つけられて体系化されう る.

仮説13 体系化された舞踊作品は比較的安定した

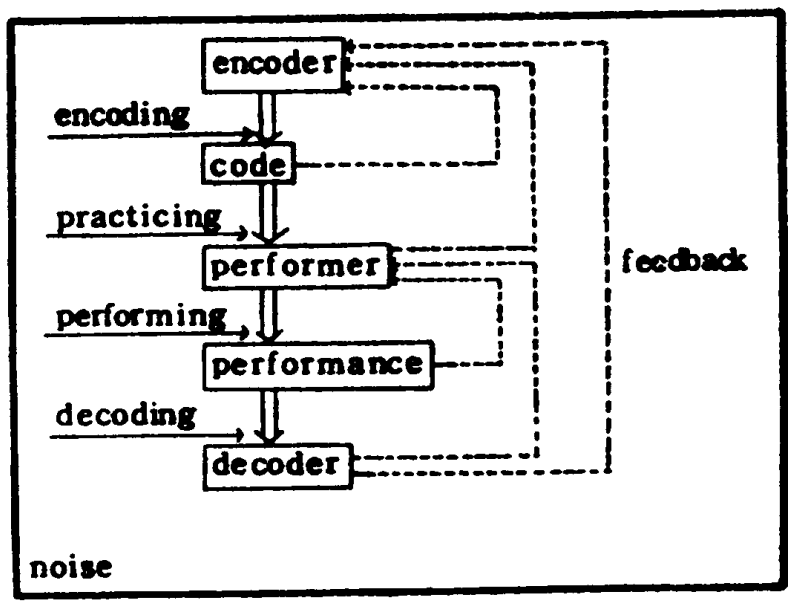

図 1 舞踊コミュニケーション・モデル

構造を持つ.

この仮説群で使用された主な用語は，ほぼ次の ような定義によって意味が限定される。

定義 1 舞踊としての記号を舞踊作品dance code または単に作品 code と呼ふ.

定義 2 ある特定の目的やアイデア,イメージを もって作品を創造するすのを，作舞者 encoder と呼び, 作品創造活動を作舞す る encoding，作舞することを作舞 encode と呼占.

定義 3 作品を修得し演じるすのを，演舞者 performer と呼び, 演じ踊り舞 5 活動 を，演舞する performing，演舞すること を演舞 performance と呼ふ。.

定義 4 作品修得や演舞の修正のための 活動を, 練習する practicing，練習することを練 習 practice と呼ら. 作品修得のための 活動は一種の解読作業である。

定義 5 作品および演舞を解誖し，評価し，鑑 賞，享受するものを，観舞者または鑑賞 者 decoder と呼び，観舞・鑑筫活動を， 観舞する，または鑑賞する decoding，観 舞・鑑賞することを，観舞または鑑鿓 decode と呼占.

定義 6 伝達には二義がある.

(1)伝達 communication とは演舞者の演 舞によって，作舞者の意罒する意味が観 舞者に伝えられることである。

(2)継承 transmission とは，作品または 
演舞するための記録媒体によって，作品 が時空を越えて伝遳されることである。

定義 7 観舞者の諸反応によって作品または演舞 を修正・適合させる作用を，フィード・ バック feedback と呼ふ。.

定義 8 観舞者による，作品の知党，記憶，想 像，判断，概念等および情埌処理に関す る心的活動を，舞踊認知と呼ふ。.

定義 9 ある有機体が他の有機体を含む環境との 相互作用で獲得した自己および環境に関 する知識を，経験と呼ふ。.

定義10 適正な作品認知またはフィード・バック を防げる要因を，ノイズ noise と呼ふ。

定義11 作舞者または演舞者が自己の作品または 演舞への認知を，自己認知と呼ぶ。

定義 12 作品が整理・分類, 関連づけられてでき あがった認知の体系を，舞踊認知体系と 呼ぶ.

仮説 1 から仮説 7 までを統合して模式圀を作成 すれば, 図1のよ5な形になるであろ5。

\section{II 世阿弥における能の㮝承と展開}

前節で揭げた作業仮説は，「舞踊」という語を 「能」に読みかえることによって，そのまま「能 の意味論」になる。ここでは, 図 1 の practicing の側面を中心にして考察する。

能継承の基本は䅞古である。『花鏡』で，「秘義 云，能は，若年より老後迄習徹するべし ${ }^{87)}$ 」説 かれるごとく，能を継承し，そして展開すること は，一生涯を種古修業に精進することである。世 阿弥は, 『風努花伝』で楮古の発達段階論を展開 し,『至花道』では, 能修業の入門が「二曲三体」 より始まるべきことを述へている；

其風体多しといへども，習道の入門は，二曲 ・三体を過ぐべからず.三曲と申は舞歌なり. 三体と申は物まねの人体也 ${ }^{88)}$ 。 二曲三体を基本とする，個人における能芸の修得 とその展開は，そのまま能芸全般の継承と展開の 前提である.「伝書」を舞踊意味論的に解釈要約 すれば,この習道過程は，困2のよ5にモデル化 することができる．図で，「先行形式」とは，舞 踊の先行ジャンル，先行作品である．舞歌を師に

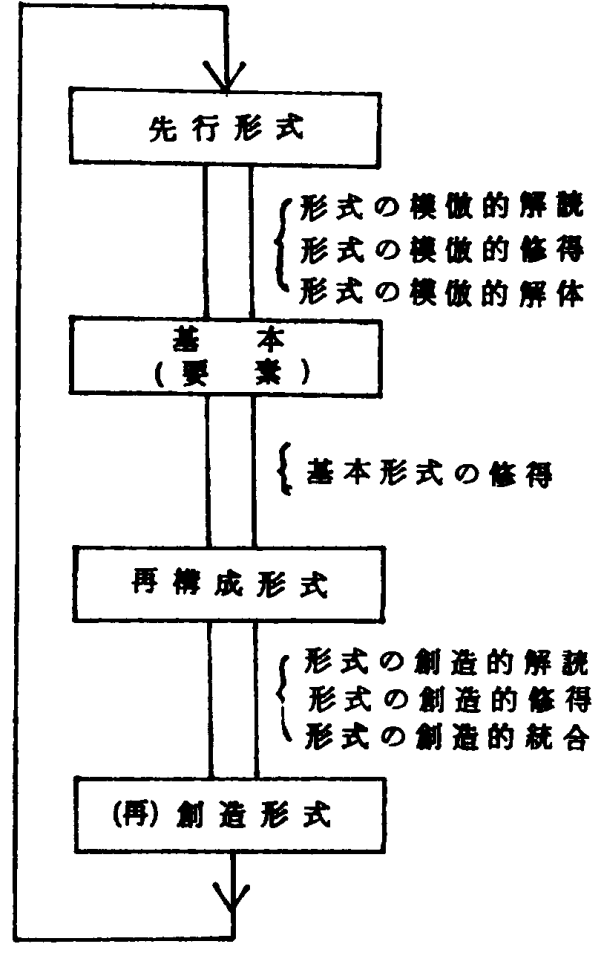

図 2 能の継承と展開

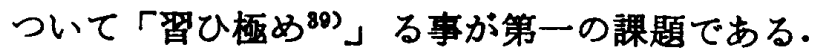
この時，「習做」するだけの「無主風」の段階か ら「有主風」に至ることが目標である。「有主風」 は次のよ5に説明される；

師によく仙せ習い，見取りて，我物になり て, 身心に觉元入て，安き位の達人に至るは， 是, 主也. 是, 生きたる能なるべし. 下地の芸 力によ(り)て, 漗い楮古しつる分力をはやく得 て, 其物になる所, 則有主風の土手なるべ ᄂ40).

因 2 で「基本形式」とは，「二曲・三体」を意 味する．「先行形式」から「再構成形式」までの 過程は，おそらく「無主風」の色柇が浱 厚であ る.そして，継承のための基礎条件の獲得とも見 なせる、それはまた演能するための基本条件でる ある。「有主風」を体得した時，継承者としての 最低条件が備わることになる「「再践成形式」と は既成作品の習得のことである，そして「再創造 形式」は，既成作品を舞台で演じることにはかな らない。

ここで，世阿弥の習道における「芸位」または 「芸風」に言及しなければならない『『九位』に おいて，彼は，芸位を上・中・下の三等に分け， さらに各等を三位に分けて，合計 9 段階とした。 
すなわち 9 位である。これを次に掲げる；

$$
\begin{aligned}
& \text { 上三花 } 1 \text {. 妙花風 } \\
& \text { 2. 脊深花風 } \\
& 3 \text {. 閑花風 } \\
& \text { 中三位 } 4 \text {. 正花風 } \\
& 5 \text {. 広精風 } \\
& 6 \text {. 浅文風 } \\
& \text { 下三位 } 7 \text {. 強細風 } \\
& \text { 8. 強鹿 } \\
& \text { 9. 鉛風(1) }
\end{aligned}
$$

世阿弥は，「中初・上中・下後 ${ }^{42)} 」$ の順序で稽古 がなされるべき事を説く，つまり，中三位から入 門し，上三花に昇り，後に下三位に降るべきこと が正統な稽古のあり方たとい5のである・このう ち，最基礎となるのは「広精風」である。広精風 を極めて始めて「有主風」の芸域に到達すること ができる。「広精風」とは；

柳, 此条々の出所者, 広精風也. 芸能の地体 にして，広く精やかなる万得の花種を顥すとこ ろ也. 然者, 広精より前後分別の岐堺，是にあ り．爰にて得花に至るは，正花園に上り，至ら さるるは，下三位に下るべし12)。 と説明されるごとく，能楽修業の要である。「広 精風」はまた「三体」であり，「浅文風」は， 「二曲」に対応する，能才のある者は，浅文風 $\rightarrow$ 広精風 $\rightarrow$ 上三花 $\rightarrow$ 下三位と芸域を拡大するが，広 精風を極め得ない者は，即時に下三位へ下るより 外ない。「正花風」あたりから，「有主風」の技 量が備わりはじめる。ここまでが，図2 と和ける 「再構成形式」の部分である・能芸の展開のため には，ここから「(再)創造形式」の過程を経なけ ればならない。これは能作品の自作および自演を 含さ.能創作の問題である. 世阿弥㑑作の能を そのレパートリーに加えるべきことを強調してい た；

能をせん程の者の，和才あらば，申楽を作ら ん事, 易かるべし、これ此道の命也 ${ }^{41)}$.

先行能作品の継承だけでなく，自作によっても能 数を増すことが「申楽勝負の立合の手立」なので ある.作能論は『三道』で詳説される。

世阿弥時代の能芸の特色を，香西は以下のよ5 に述べている；
(1) 世阿弥時代の能は, 生き生きとした創造の芸 術であった：新作が相競い，相ついで上演さ れていた。まさしく能の大成期であった。

(2) 上演の都度, 台本にも演出にも, 創意と工夫 が加えられ，改訂に改訂が重ねられた ${ }^{20)}$ 。 このよ5な状況をくぐり抜けて作品のあるもの は, やがて「古典」の地位を獾得することにな る。

以上の論議を一般化して考えれば，図 1 の 「practcing」の部分が，図2の「先行形式」か ら「(再)創造形式」直前の全プロセスに拡張され たことになる。

\section{III 二曲三体エフォート酾}

ここでは, 図 2 の「基本 (要素)」を中心にして 検討する.三体論もエフォート論も，舞踊におけ る基脴動作論とみなすことによってこれらを「基 本(要素)」に組み込んで両者の比較を試みる.

『至花道』に，「かやうの奥風を見るに付けて む, 初めの二曲三体の習風を，立かへり立かへり 見得すべし45)」と述べられるごとく，「二曲三体」 は能の基本である。すでに見たよ5に，「二曲」 とは歌舞であり，「三体」とは，「老体・女体・ 軍体 ${ }^{46)}$ を意味する.『二曲三体人形図』から， これら三体の特質を抽出すると；

(1) 老体：閑心遠目

(2) 女体: 体心捨力

(3) 軍体 : 体力砕心 ${ }^{47}$

となる。これら三体を基本形として，その忍用風 が展開される；

(1) 老体の用風：神さび閑心なるよそをひ，

(2) 女体の用風：幽玄みやびたるよしかかり，

(3) 軍体の用風：身動足踏の生曲 ${ }^{48)}$,

であって，老体 $\rightarrow$ 老舞，女体十女舞・天女舞，軍 体 砕動風の対応つけがなされる49).「形鬼心人 を眼目とする砕動風は，軍体の用風であるだけで なく，「若者・貫男・狂女など」のヴリエーシ ョンを内包する50).

世阿弥は，「能に体・用の事を知るべし 『至花道』に書いている.「体・用」は次のよ5 に敷衍される；

1) 心にて見る所は体也. 目にて見る所は用也. 
2）能を知る物は，心にて見るゆへに，体を似す る也・体をよく似する内に，用はあり。

3）体・用といふ時は，二あり。体なき時は，用 ああるべからず。

4) 用を似すれば体になる理を安得せば，体・用 の分目をよく心得たる為手なるべし22.

「体」は理想型である．演じられる動きは「用」 である．観能者は「用」によって「体」を見る。 次に「二曲」の問題を考劣る。『二曲三体人形 罒』は，二曲と三体の連関を次のよ5に記してい る ;

此二曲习能々学得し次れハ, 舞歌一心一風二 なりて，安久長曲之達人ト成ベシ. 其後, 児 姿三体ニ5つして二曲をなせば，をのつから， 幽玄之見風，三体二あらハるべし．三体ヨ児姿 ノ間しばらくなさす゚して，児姿を三体に残す 事，深手立也.たた，最初ノ児努二曲を習得し $\tau$, 長久之有主風二安得するゆへ二, 三体にも 残り，万曲之生景二も成也 ${ }^{49)}$.

「二曲」と「三体」は相互に含み含まれる関係に ある. 二曲を前提とし，三体があり，三体の中に 二曲は残される。

梅原は「舞歌とは，世阿弥の能においてはある 人間様式を表現する手段であり，三体とは，その 表現すへき人間の生命の存在をい5のである」と

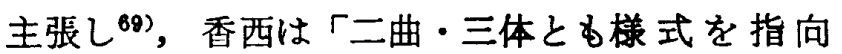
し，しかも，全体として有機的に統一することが 強く要請される21〉」と，二曲・三体を説明してい る.

以上の所説を5けて，次に「三体論」と「ェフ ォート論」との関連つけを試みることにする。た だし，ここでは，世阿弥の模做の理想型モデルと しての三体を，「体」ではなくその有する「用」 すなわち「動き」の側面に視点を定めて論じるこ とにする・

ラバンは, 時間 (Time), 力性 (Weight), 空間 (Space) の三つの運動因子を設定する ${ }^{22)}$ ，時間は 運動の速度 (緩急, Ssustained/Quick),力性は運 動の強度 (軽重, Light/Strong), 空間は運動の柔 㳄度（曲直，Flexible/Direct）を表わすと考えら れる.これら三因子を相互に直交させると，身体 運動の基本要素の模式因が図 3 のよ5に構成され

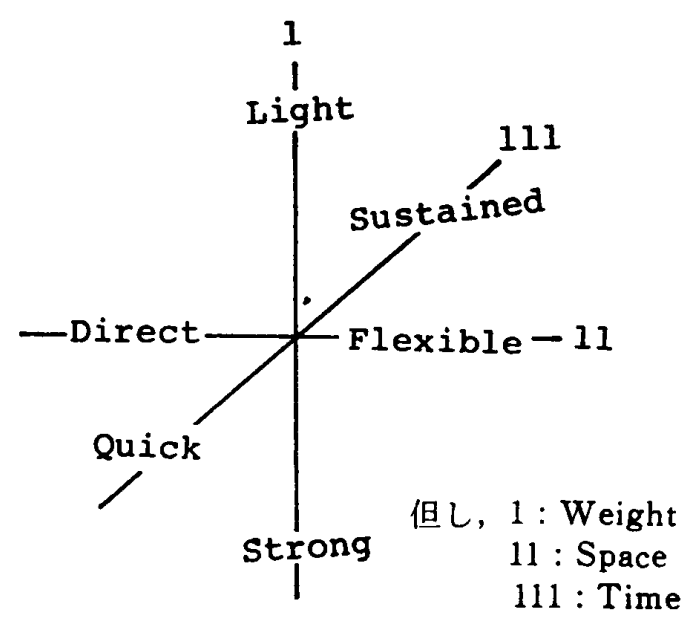

図 3 身体遇功の基本要来

る. 運動要素の三種の方向性の組み合わせによっ て8個のエフォート・エレメントが抽出される (四 4，および表 1 参昭).エフォート・エレメン 卜は運動因子に媒介された基礎的身体動作の 理想 型である・これらが具体的に運動（動作・動き） として解発 release されることを，エフォート・ アクションと呼ふ・エフォート・エレメントは 「体」に，そしてェフォート・アクションは「用」 に対応つけて見ることができよ5。

時間, 空間, 力性は, それそれ䌅, 曲, 軽に調 和し, 急, 直, 重飞対立する ${ }^{28)}$. 時間, 空間, 力 性の備える性質と，既述した世阿弥における老 体，女体，軍体の特徽を考㦄して両者を対比する と，次のような相同性を認めることができるであ ろ 5 ;

老体一時間 $/$ 関心遠目一緩
女体一空間 $/$ 体心唅力一一曲
軍体一一性 $/$ 体力砕心—重

表 1 ラパンのエフォート

\begin{tabular}{l|l|l|l}
\hline Effort & Weight & Space & Time \\
\hline Float & Light & Flexible & Sustained \\
Glide & Light & Direct & Sustained \\
Press & Strong & Direct & Sustained \\
Wring & Strong & Flexible & Sustained \\
Flick & Light & Flexible & Quick \\
Dab & Light & Direct & Quick \\
Thrust & Strong & Direct & Quick \\
Slash & Strong & Flexible & Quick \\
\hline
\end{tabular}




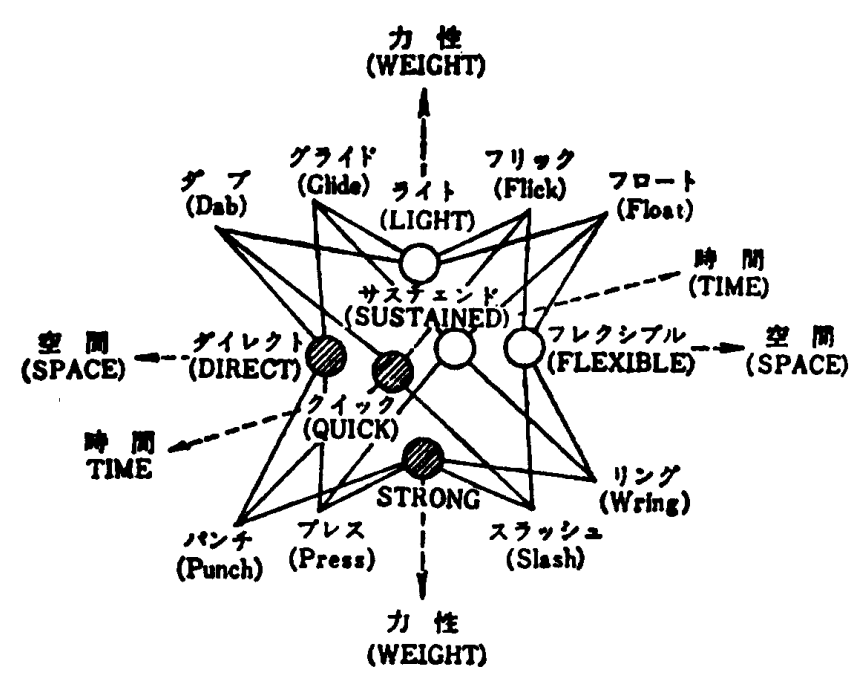

図 4 運動要素と基碟動作 ${ }^{28}$

この対応つけは試論の域を出ないもしこれが妥 当であるとすれば，図4 および表 1 に見られるよ 万に，時間軸の Sustained 側が，老体のヴァリエ ーション, 空間軸の Flexible 側が, 女体のヴ, リエーション，そして力性軸の Strong 㑡が軍体 能のウァリエーションとして位置つけが可能であ る・たとえば，空間軸の女体についていえば，女 舞をたは天女舞とは, Float, Wring, Flick, Slash のエフォート・アクションの要素の多い作品であ ることが予想される，しかしこのことの実証は本 稿の範囲外であり，残された問題として後日を期 したい。

エフォートは，基本運動であり単一の動きであ る.これら単一の動きの連続的組み合わせは，身 体運動に無限のヴァリエーションを生み出す。そ して，舞踊の各シャンルに独自なその特性に従っ た数多くの作品の創造を可能にする．ラバンは音 楽における楽譜に対比されるような舞踊における 記譜法としての，エフォート・グラフを開発して いる・能研究へのエフォート論の導入は，記譜法 や分類法 ${ }^{16)}$ に新しい知見を加えることを可能にす ると思われる. しかし，これもまた残された問題 である。

\section{IV 演能週程三見的}

三見とは，「我見」「離見」，「離見の見」を表 わす.「三見論」は，「目前心後」をめぐって， 特に「離見の見」説として論ぜられる，世阿弥は 『花鏡』で以下のように述べている；
舞に，目前心後と言事あり。「目を前に見て， 心を後に置け」となり，是は，以前申つる舞智 風体の用心也. 見所より見る所の風努は，我離 見也・しかれば，我眼の見る所は，我見也. 見の見にはあらず.嚄見の見にて見る所は， 則，見所同心の見なり。其時は，我努を見得す る也.我姿を見得すれば，左右前後を見るな り.しかれ共，目前左右までをば見れどあ，後 努をばいまだ知らぬか。後姿を觉えねば，努の 俗なる所をわきまへず。さるはどに，離見の見 にて，見所同見と成て，不及目の身所まで見智 して，五体相応の幽をなすべし，是則，「心 を後に㯰く」にてあらずや，返々，離見の見を 能々見得して，眼まなこを見奴所を觉えて，左 右前後を分明に安見せよ. 定て花努玉得の幽舞 に至らん事，目前之証見なるべし38．

「目前心後」の顧虑は，演能者の演能心得である と考えられる、「目前心後」のための具体的方策 として「離見の見」が説かれるのであるここの説 は, 演能過程の構成要素として「観客」を取り込 んだ吅妙な演能者論である. 舞踊意味論的に見 て, 戸井田は妥当な意見を述べている．すなわち 「能には，観客と舞台をへたてる幕が無い。観客 は席についた瞬間に，む5，能の世界に面と向か

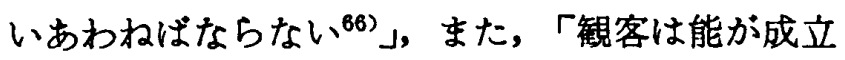
するために欠くことのできない構成要素だったの

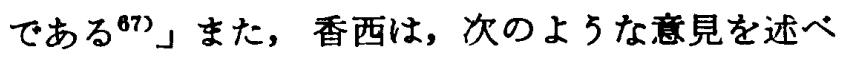
ている;

能のよ 5 な象徽的な舞台芸術は，俳優が舞台 につつり出す象徽を, 観客が解釈し, 意味つけ をすることによって，はじめて成立する ${ }^{(9)}$.

この視点の導入をもってはじめて，「舞解コミュ ニケーション・モデル」は完成される.

我見, 離見, 離見の見, いずれも問題は「見」 である. 演能演者論は, 能役者の側からすれば 「見せ方」「見られ方」が重大である。山崎が， 世阿弥の伝专を「つねにく見られ>ながらく見せ

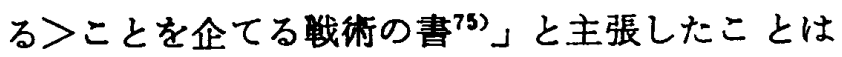
正鵠を射ている，「見せ・見られる」演能者の 「風努」または「見風」は「見兄 appearance」 である。「見え」を効果的にならしめるための工 夫が「目前心後」の教えなのである。 
演能者自身による自己の演能（風姿）の知堂を 「我見」と呼ぶ。しかし，「眼まなこを見 $2^{54) 」 ~}$ のであるから，鏡やVT R Rをはフィルムの助け を借りなくては，自己の風姿を視ることができな い.そ5すると，観能者を鏡などに見たてて，演 能者は自己の風姿を見るしかない。観客の㑡か ら，演能者の風姿を見ることが，「離見」であっ た.この場合，観客の視觉は決して演能者の視觉 ではない，観能者の視ている眼で演能者が自己の 演能する風姿を見ることが「離見の見」である. これが「見所同心の見」である，「離見」でもっ てしては，演能者の風姿の後㑡面を見ることはで きない。すなわち，「見所同見」となる「離見の 見」でなければ，「不及見の身所まで見智」しう るはずがない，この不可能事を，世阿弥は「心を 後に置く」ことによって「見る」のである．演能 者の前後左右のうち，後を除く 3 側面を「目」で 見て(離見)，後側を「心」で見るというのである (「離見の見」). 現代のカメラ技術は，視覚のみで これを可能にする．だが収録され，映し出された フィルムの中で見る演能者の演能 performance は，すでに演じた当の演能者を一人の観能者にか えてしまっている.このことは，执そらく次回の 演能のための反省材料を提供するが，演能中演能 者には，ついに「目前心後」の不可能なことを意 味するすのであろ5.テレビ・カメラによる自己 の演能の同時視取は，䅝古練習中ならともかく， 演能舞台では不可能である. 演能は常に生身の演 能者にとって，観能者との間に緊張関係を持続し ながら，現示的形式として「現在」する一回性の 試みなのである。

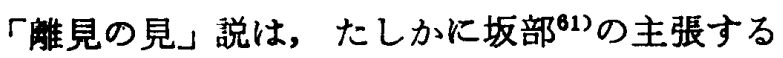
ごとく「相互変換的な根源的なくメタフォル〉」 の一面をるつ．だが，演能者と観能者の位圆関係 は，必らずしす相互に変換可能なのではない，相 互に変换された視点で，観能者の目で見た「見」 は，離見であって，「離見の見」にはなりえない。

「離見の見」に招いて，演能者は，我見を持ちつ つ，離見で自己の風努を見て，さらに「見つつ・ 見られる」ことを見ている。他の演能者による演 能の観能経験は，「触見の見」で見ることの訓練 においては，言うまですなく重要である．視知觉
を手段とし，しかも自身を伝達記号化する芸術シ ヤソルでは，ついに直接的に自己の演技を視るこ とはかなわない。

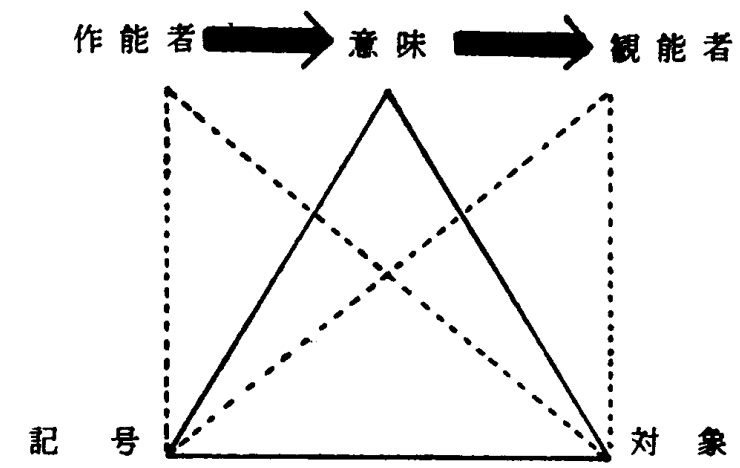

(演能者)

図 5 演能過程の概念モデル困

作能者の「意中の景」は演能者の「意中の景」 として「記号」化され，その「見風」を観ること によって作能者は, 観能者と相互変換的位置関係 を成立させる.この演能過程をモデル化すれば図

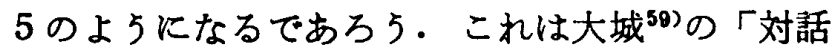

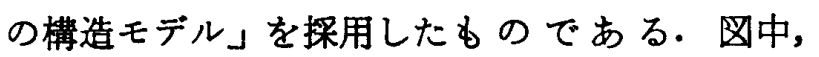
「記号」とは，演能者 performer が素材となって 現示的形式となったるのをあらわす。作能者 encoder は演能者を記号化することにより，その 「意中の景」に込めた「意味」を観能者に伝達す る. 観能者 decoder は, 演能者の現示的形式とし ての記号に付与された「意味」すなわち，作能者 の「意中の景」を解珫・鑑賞する。

実際の演能過程, つまり舞台上での演能中に は，演能者と作能者が同一人でないかぎり，作能 者は，想定された位圈を占めるに過ぎない，舞台 で対峙するのは，演能者と観能者である．作能者 は，自己の身体を素材として身体運動による記号 化 performing を試み, その結果は作品 performanceを現出せしめる. 演者にとって, 演するこ とは，作者の「意中の景」の解読作業の具体化で ある. 演能とい5一回的な記号化の過 程におい て，「目前心後」が語られているわけである・絶 えず，現われては消失していく身体による動きの 連秸性の中に, 観能者の諸反応が演能者にフィー ド・バックされていく，演能者と観能者との交互 作用に打いて双方が変転しつつ演能は完結する. この過程で，世阿弥は，演能者に自己の風姿の 
「前後左右」を見ることを求めていたのである。

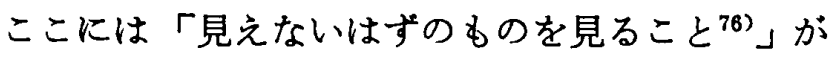
要請されている．「嚄見の見」は，演能者が自分 の見風を客観的に，あるいは分析的に把握するこ とではない.「自分の運動の流れの全体をひと息 に直観によって把握することであるらしい、77」と は，山崎が述へているところである.われわれ は，ここで「離見の見」説を演能者の自己の演能 の知党ないし認知の問題として読み解いてみた い.

Miller は,「言葉 speech は聴覚的に聴き手に 影響するのと同じように話し手にも影響するとい 万興味深い特性を有している。かくして，すべて 話し手は，自身の德き手であり，他者に反応する のと同じょ5に，自分に反応するとい5ことも，

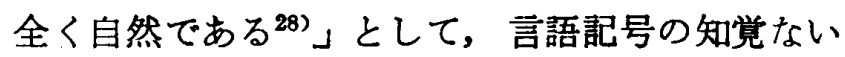
し認知の特性を述へていた。山元はこれを Mead ${ }^{27)}$ に上って，次のよ5に読みかえる;

ミードは自己外化的に語り出しつつあるもの を“「”と名つけ，語り出されることによって聞 かれつつあるものを“me”とよび, “I”を"me” として語り二聞きつつあるものを本来的な人格 としての “self” とい572).

ミードの理論は, 記号行動論やシンボリック・相 互作用論, そして自我の社会心理学へ引き継がれ ていく. 船津は, ミードの人間行動観の特性の 1 つが，「シンボリックな相互作用過程において， 人間の<自我 self>が形成される2)」点であるこ とを述べた上で，「自我」の機能を次のよ5に主 張している；

これらの「自我」「マインド」「思考」は, 人間をして，他者に対し適応させるだけの存在 から，他者を選択し，解釈し，修正し，動きか け，変化させ，新たなるのを創造する積極的で 能動的かつ主体的存在たらしめる

このよ5に説明される「自我」理論を演能過程の 解読に適用することがここでの課題である。ま ず，演能者の風努に着目すれば，演じて「見せる」 ことが“I”であり，演じることによって「見られ る」風姿が “me” そして「見せ・見られ」ている 風努が “self” に対応することは明白であろ5。 そうすると，I $\rightarrow$ 我見， me $\rightarrow$ 離見, self $\rightarrow$ 離見の
見として，この自我理論を拡張することは妥当で あろう。

演能者は，三見のいずれをもってしても，自己 の演能を見ることはかなわなかった。彼が見るの は, (1)自己の演能の風努についての自己の想像, (2)観能者の眼に映っている自分の風努についての 彼自身の想像，(3その風姿に対する観能者の判断 についての彼自身の想像，そして(4)これら想像に 対する反応である誇りとか口惜しさなどの自己 感情，である ${ }^{70)}$ 。この5ち，(1)は我見と見なせ る. (2)は離見に近い，そして(3)と(4)は離見の見と 解釈できるこ5見てくると結局，「見」とは自 己概念の機能ということになる．我妻は「個人に 対する周囲の人びとの態度行動の如何によって， その個人の自己概念または，自己感情が規定され ている事実 ${ }^{71} 」 に$ 言及している。この指摘はその まま，演能過程における演能者と観能者の関係に も妥当するであろ5. 観能者の演能者の演能への 諸反㤁は，演能者の I を映す鏡であり，これはま た，嚁見たる me であって，即時的に self に連 動して，再びIを突き動かす．演じる主体I の演 能を self は，「離見の見」の役割をとることによ って制御している.

加藤は，「能楽論における世阿弥の問題は，第 一義的には，と5い5能がよろしいか，ではな くぞういち能が観客の気に入るか，であった 10)」と主張するが，この場合，演能者は単に観能 者の反応に適応するだけではなく，「働きかけ変 化させ名」るべき対象であある。「世阿弥の関心 は，勝負にあり，勝目を決めるのは，観客だ ら，演技が観客に与える効果は，当然その関心の

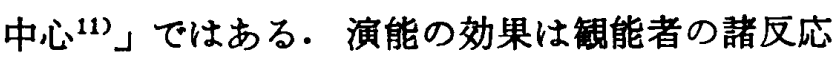
として現われる，演能者にとって観能者は「詐術 をもってしても応酬すべき敵手のような存在 ${ }^{78)}$ となるすのもやむを得ない，しかも，観能者の中

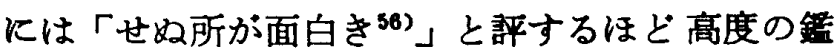
賞眼を有する者がいたのである。このような観能 者に対処する方策が「目前心後」説であったであ ろ5.「目前心後」をもって演ずる演能者の「後 努」を看取することが観能者にとって「せぬ所が 面白き」と感じられたのであろ5．「後姿」をめ ぐって演能者と観能者は死力を尽す．そこで世阿 
弥は，心を後に置くことによって「姿の俗なる 所 ${ }^{54} 」$ を避けつつ「用心を持つ内心 ${ }^{36)}$ 」を論ずる; 此内心ありと，よそに見えては悪かるへし。 もし見えば，それは態になるべしせせ奴にては あるべからず。無心の位にて，我心をわれにる 隐す安心にて，せぬ隙の前後を綰ぐべし，是 則, 万能を一心にて綰(゙感力也 ${ }^{56)}$.

「内心」とは「心後」の工夫である，演能者は， この工夫を観能者たけでなく自分自身にす鿵せと い5のである．ここに至って，「目前心後」すな わち「離見の見」説は解消されてしまう。「我心 をわれにも隐す安心」を演能者に要求した世阿弥 は，これに即応するかのように，観能者に対して， 出来庭を忘れて能を見よ，能を忘れて為手を 見よ・為手を忘れて心を見よ，心を忘れて能を 智れ ${ }^{37}$

と説いた．演能過程における作品演能を介した， 演能者と観能者の息つまるような相互作用が，こ こには述べられている。これは，すはや「目前心 後」も「せ妡が面白き」る越えられた次元の問

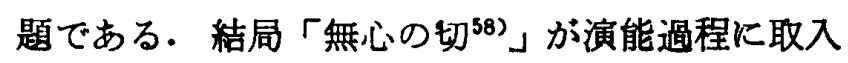
れられ「心はなくて面白きと5けがうとは何物 ぞ58)」と発問される状況を設定しながら，世阿弥 はこれに対してついに解答を与えていない。

\section{おわりに}

本稿は舞踊意味論的観点から世阿弥能芸論 の特 質を(1)䅦古論，(2)二曲三体論，(3)三見論 (「離見の 見」論）を中心に検討した。さらに，この分析を 通して得られた知見を，舞学意味論仮説にフィー ド・バックさせ，その增補改訂を試みた。

まず，稳古論は世阿弥が強調してやまないるの である.能芸は, 二曲三体を基本とし，稀古もこ れより始まり，これを極めることによって能芸の 继承と展開が可能になる。 また，自作能を持つこ とが能勝負に勝つ手立である。

ついで，三体論を能における動きの基本パター ンに関する諭と解しこれをラバンのェフォート 論と比較対照し，両者の類似性について 検討し た。

最後に，「目前心後」説に関わる「離見の見」 論を中心とした三見諭を演能過程論として，ミー
ドの自我心理学の知見を採用しつつ考察した。

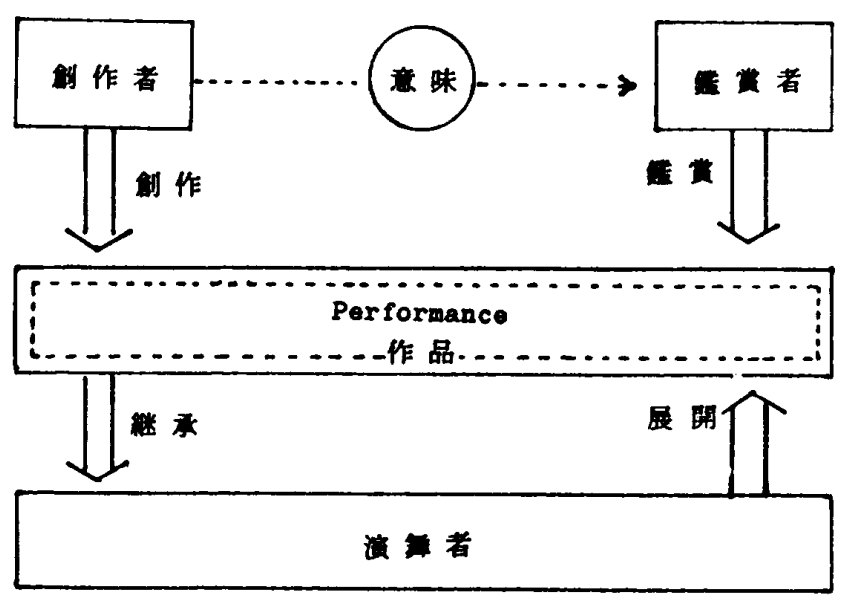

因 6 舞捅過程の綮念モデル図

以上の分析で得られた結果を整理，要䄪，単純 化し，舞踊過程を模式化して困示したのが困 6 で ある. 本図は, 能芸に限定しないで, 舞踊の一般 論として理解されたい，大まかな説明を試みる。

1) 作舞者は, 創作機能を, 鑑賞者は, 鑑賞機能 を有する。

2）作品の「意味」は，演舞者による演舞を媒介 として作舞者から鑑貴者に伝達される。

3 ）演舞者は, 作品の継承機能と展開機能を有す る.

4.）「継承」は既製ジャンル，既製作品の修得を 中心とした綀習過程を主機能とする.

5)「展開」は，既製作品および新作（含自作） の演舞過程である。

6 ）演舞者と鑑賞者は演舞によって対峙し，相互 に規定しあ5.

ここに示したモデル図は，舞硧の総合理論の確立 を最終目標においた渐定的な結論であり，今後， 增補改訂されなければならない。

$$
\text { （付 祀） }
$$

本研究の実施にあたって終始ご指夏いただいた琉球大

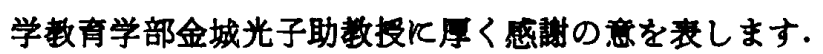

本稿の作成にあたって，縟集部より貫重なご助言を受 けました．記して感期申しあけます。

\section{文献およひ注乩}

1）新井恒易：『能の研究」新誖湆社 1966. 
2）船律 街『シンボリック相互作用铪』P.102, 恒星 社 厚生閣 1976.

3) 同害 p. 103 .

4) 古川 久：『世阿弥・芭蕉・馬琴」東京䅅済新聞社 1969.

5 ）後藤 淑：『能の形成と世阿弥』p.137, 木耳社 1966.

6）金井清光：「能の研究】松風社 1967.

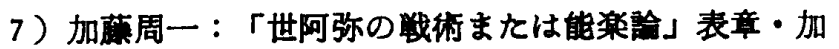
藤周一，校注：「世阿弥 椫竹』（日本思想大系24） pp. 515 541 岩波書店 1975.
8) 同毒 p. 515 .
9) 同書 p. 524 .
10) 同書 p. 529 .
11) 同毒 p. 530 .

12）金城光子・大城冝武：「舞踊の認知構造について一 舞踊コミュニケーション・モデル試呤」『日本体鬲学 会25回大会号』p.121，1974.

13) ：「舞解要知の意味論的研究（その

一)」「琉球大学教育学部紀要」第18策, 第 2 部.

pp. $27 \sim 39,1975$.

14) ：「舞踊裙知の因子分析的研究：IJ

『体青学研究』第22卷，第 2 号 pp.101 117 1977.

15）北川忠彦：『世阿弥』p. 12 中央公論社 1975.

16) 同書 p. 126.

17）小西甚一・草深 清：「世阿弥の作品と芸術諭」

『文学』v. 31. no.1. pp. 25～35, 1963.

18）香西 精：「世阿弥時代の能と今日の能」「文学』

v. 31 no.1. pp. 1 12, 1963.

19) 同要 p. 11 .

20）同素 p. 2 .

21) 同爵 p. 9.

22）ラバン， $\mathbf{R}$.（須藤智惠・秋葉母子，訳）：『現代の 教育舞踊」明治図書 1974 (Laban, R. : Modern Educational Dance. 1948)

23）同毒 p. 50 .

24) Laban, R. and Lawrence, F.C.: Effort, McDonald \& Evans. 1965.

25) Langer, S.K.: Feeling and Form, Charles Scribner's Sons. 1953.

26）增田正造：「能の表現』中央公諭社 1974.

27) Mead, G.H. : Mind, Self, and Society,The University of Chicago Press. 1972.

28) Miller, G.A. : Language and Communication. McGraw-Hill. p. 172, 1963.
29) Miner, E.: The Japanese Tradition in British and American Literature. Princeton University Press. 1958.

30）西一祥：『世阿弥研究』さるびあ出版 1967.

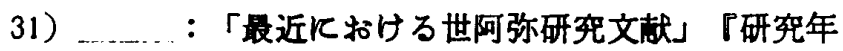

報』（日本大学文学部）第20桿 pp. 48〜 72, 1971.

32）西尾 実：『世阿弥の芸能論』岩波言店 1974.

33）能势朝次：「能集琴源流考』岩波書店 1956.

34）表 章：「世阿弥」全国大学国語国文学会, 綢:

「敦坐日本文学 6』pp. 165 192, 三省堂 1969. 35） ….... : 「世阿弥之禅竹の伝書」表章・加藉周一, 校注：『世阿弥 禅竹』 pp. 542 582, 岩波書店 1975.

36）表章・加藤周一, 校注：「世阿弥禅竹』（日本 思想大系24）岩波畫店 1975. 本書を世阿弥伝書のテ キストとして使用し，世阿弥よりの本文での引用はす ベてこれによる.

37) 同書 p. 106.

38）同書 p. 112.

39）同書 p. 113.

40) 同畫 p. 114 .

41) 同書 pp. 174 175.

42) 同書 p. 176.

43）同書 p. 176.

44) 同書 p. 30.

45) 同書 p. 116.

46) 同書 pp. 112 113.

47）同書 pp. 124 127.

48）同書 p. 113.

49）同著 pp. 124 128.

50）同费 p. 128.

51) 同害 p. 117.

52）同毒 pp. 117 118.

53) 同書 pp. $88 \sim 89$.

54）同毒 p. 88.

55）同上

56) 同書 p. 100.

57）同毒 p. 104.

58) 同書 p. 189.

59）大城冝武：「意味の意味論的研究」『心理学評諭 V. 18, no.2. pp. 59 74, 1975.

60）プレストン，V.（松本千代栄, 訳)：『モダンダ

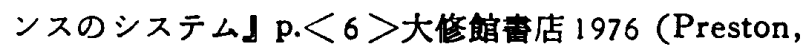
V.: A Handbook for Modern Educational Dance 1963) 
61）坂部 恵：『仮面の解釈学」東大出版会 1976.

圾部は，「䊒見の見」説について次のように述べてい Ђ;

「この有名な世阿弥の「離見の見」の説は，なまじ <現前の形而上学>からする二元詥的・実体論的な思

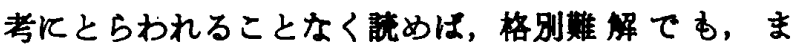
た，おそらく，ことさらに深迲ですないはずだ.ここ には，ただ前と後，〈おすて〉とくうらて〉，自己と 他者の相互变换的な，根漂的なくメタフォル>の思考 が述べられているだけであり，これを理解するのに近 代の心理学や現象学のく想像力などをあってするこ

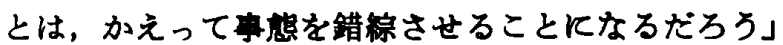
(p. 16).

62）答原道太郎：「欧米における世阿弥研究」「文学』 V. 31. no.1. pp. $95 \sim 113,1963$.

63) Snygg, D., and Combs, A. W.: The phenomenological approach and the problem of "unconscious" behavior. Journal of Abnormal and Social psychology. v. 45 pp. 523 528, 1950.

64）竹内敏雄, 監修：『芸術記号論』（講座・美学新思 潮 3）美術出版社 1975 .

65）田中裕, 校注：『世阿弥芸術論策』（新潮日本古 典集成 4 ）新湖社 1976.

66）戸井田道三：「能一神と乞食の芸術』 p. 28. 每日 新閪社 1964 .

67) 同畵 p. 34.

68) ：『観阿弥と世阿弥』 岩波量店 1974.
69）梅原 :「世阿弥の芸術詥」『文学」V.33. no. 6 . pp. $35 \sim 49,1965$.

70）我妾 栄：『自我の社会心理学』pp. 4 5 諴信满 房 1964 .

71）同毒 p. 5 .

72）山元一郎：『コトバの哲学』p. 335，岩波書店 1967.

73）山崎正和：「变身の美学」, 山崎正和, 细,「世阿弥」 （日本の名著10） pp. 7〜2. 中央公敛社 1964 .

74）同豊 p. 40.

75）同粪 p. 62 .

76)同蛪 p. 57 .

77）同量 p. 58 .

78）同素 p. 44

79）山崎正和，编：『世阿弥』（日本の名著10）中央公 論社 1964.

80）座铁会「世阿弥研究の回朢と展望」「文学』V. 31 . no. 1. pp. $114 \sim 128,1963$.

この座談会て，表 章は「能楽論研究ですけれどす， 全国で発表される世阿弥咸保の論文はかなりの数に上 っていますが，鿁んでみると，半分近くはこれはどこ かでだれかが以前に同じようなことを言っていた，と いう程度のすのじゃないかと思うのです」と述べてい る. (p. 128)

81) 同毒 p. 128.

82）座談会「能䑁研究の展望」「文学』V.41. no. 7. pp. $88 \sim 114,1973$. 